\title{
HAEMATO-BIOCHEMICAL ALTERATIONS AS BIOMARKERS OF LEAD INDUCED TOXICITY IN MALE WISTAR RATS
}

\author{
B. S. Okediran ${ }^{1^{*}}$, O. B. Kasali ${ }^{2}$, S. O. Omotainse ${ }^{3}$ and O. A. Akinloye ${ }^{4}$ \\ ${ }^{1}$ Department of Veterinary Physiology and Biochemistry, Faculty of Veterinary Medicine, University of Ilorin, \\ Kwara state, Nigeria; ${ }^{2}$ Department of Veterinary Pathology, Faculty of Veterinary Medicine, University of \\ Ibadan, Oyo State, Nigeria; ${ }^{3}$ College of Veterinary Medicine; ${ }^{4}$ Department of Biochemistry, Federal University \\ of Agriculture, Abeokuta, Ogun state, Nigeria
}

\begin{abstract}
The present work is devoted to access some of the biomarkers due to lead toxicity in experimental Wistar male rats orally exposed to graded doses of lead (200, 300 and $400 \mathrm{ppm}$ of lead as lead acetate) over a period of four, eight and twelve weeks. A total of sixty Wistar male rats were equally divided into four groups A, B, C and D. Group A served as control. Groups B, C and D were exposed to 200, 300 and 400 ppm of lead as lead acetate respectively. At the end of four, eight and twelve weeks, five animals each were removed from each group; blood sample was obtained via the ocular median canthus for haematological and biochemical studies. The results indicated accumulation of blood lead which was both dose and time dependent, while there was significant decrease $(\mathrm{P}<0.05)$ in packed cell volume and haemoglobin concentration. The erythrocyte indices (mean corpuscular volume, mean corpuscular haemoglobin and mean corpuscular haemoglobin concentration) also revealed a significant decrease, revealing microcytic hypochromic anaemia. There was significant decrease $(\mathrm{P}<0.05)$ in both the total plasma protein and albumin while blood urea nitrogen and creatinine revealed a significant increase, giving an indication of compromised liver and kidney functions. It was concluded that oral exposure to lead at vary doses over a period of four, eight and twelve weeks results in alterations of various haematological and biochemical parameters and thus can serve as a sensitive biomarkers in lead toxicity.
\end{abstract}

Key words: Albumin, anaemia, blood urea nitrogen, creatinine, protein.

\section{INTRODUCTION}

Lead is a ubiquitous environmental toxin that induces a broad range of physiological, biochemical and behavioral dysfunction. It has being recognized as the major heavy metal pollution because of its wide distribution in the human environment (Harison and Laxen, 1981; Finkel et al., 1983). Many reports are available regarding lead toxicity and its deleterious effects in various species of animals. It is a major environmental pollutant and its toxicity continues to be a major public health problem and there is a growing consensus that lead cause toxic injury to human at a level of exposure that was considered to be safe a decade ago. Chronic exposure to lead, even at low levels, can result in slow progressive, in most time, irreversible damage to haemopoietic nervous and renal system (Silbergeld 1997; Nevin et al., 2008).

Blood or blood constituents are the best indicators of the present internal exposure of an individual to lead (Lanphear et al., 1999), however blood lead levels alone does not always give an accurate estimate of total body burden of lead, hence it is important to detect sub cellular damage using reliable sensitive biomarkers. Animals are very good indicator of the environmental pollution, as they inhabit the same space as humans and are exposed to the action of the same pollutants, for this reason it is appropriate and advantageous to evaluate the negative impact of the polluted environment by lead and their influences on human health by parallel evaluation on the animals. Hence this study is to evaluate some of the haemato-biochemical alterations induced by lead acetate toxicity in male Wistar rats in addition to blood lead concentration at varying doses in experimental male Wistar rats that can serve as sensitive biomarkers in lead toxicity.

*Corresponding e-mail address: okediranbabatunde@gmail.com Copyright @ 2016 Bangladesh Society for Veterinary Medicine 


\section{B. S. Okediran and others}

\section{MATERIALS AND METHODS}

\section{Experimental animals}

A total of sixty male Wistar rats were used for this investigation. The average weight of the rats was $152 \pm 3.5 \mathrm{~g}$. They were provided with laboratory animal feed (Fat/oil 6\%, Crude fibre 5\%, Calcium 1\%, Available phosphorus 0.4\%, Lysine 0.85\%, Methionine 0.35\%, Salt 0.3\%, Crude protein 18\%, Metabolisable Energy 2900 Kcal.kg ${ }^{-1}$, Manufactured by TOPFEEDS ${ }^{\circledR}$, Lagos, Nigeria) and water provided ad libitum. Experimental animals were acclimatized to their housing environment one month before the start of the experiment.

\section{Animal ethics}

All experimental protocols carried out on the animals were in accordance with the internationally accepted principles for laboratory animal use and were approved by the Ethics Committee on Laboratory Animal Use of the College of Veterinary Medicine, Federal University of Agriculture, Abeokuta.

\section{Administration of lead acetate}

The animals were randomly divided into four groups of fifteen animals per group and were treated with lead acetate orally as the source of lead exposure for a period of four, eight and twelve weeks. The treatments were as follows: Group A: served as the control and were given distilled water. Group B: were given 200 ppm (parts per million) of lead as lead acetate. Group C: were given 300 ppm of lead as lead acetate. Group D: were given 400 ppm of lead as lead acetate. Lead acetate, $\left(\left(\mathrm{CH}_{3} \text {. COO }\right)_{2} \mathrm{~Pb} .3 \mathrm{H}_{2} \mathrm{O}\right.$, Assay (ex $\left.\mathrm{Pb}\right)$ 99-103\%, Maximum Limits of Impurities, Chloride (Cl) $0.005 \%$, Copper (Cu) 0.002\%) a product of Cartivalues, England.

\section{Haematological studies}

Blood lead concentration were determined in whole blood using atomic absorption spectrophotometer (Buck 200) a product of Buck scientific, Connecticut, U.S.A. At the end of four, eight and twelve weeks of lead treatment, blood samples were collected via the occular median canthus using heparinized capillary tubes into heparinized tubes. Packed cell volume, red blood cell and white blood cell count and haemoglobin concentration were determined as described by Jain, (1986)

\section{Plasma preparation}

The blood samples were centrifuged at $4000 \mathrm{rpm}$ for 10 minutes to separate the plasma from the red blood cells (erythrocytes). The plasma was then removed and stored in Eppendorf tubes for further analyses.

\section{Biochemical studies}

Total plasma protein and albumin concentrations was estimated according to the method of Tietz, (1995) and Grant, (1987) respectively by using commercial kits (Randox®, Spain). Plasma blood urea nitrogen and creatinine concentrations were estimated according to the method of Henry, (1974) by using commercial kits (Cromatest ${ }^{\circledR}$, Spain).

\section{Statistical analysis}

Results were expressed as mean \pm SEM. Analysis of the data was done using one-way analysis of variance followed by the Duncan multiple range test. A p value $\quad 0.05$ was considered significant in all cases.

\section{RESULTS AND DISCUSSION}

The mean blood lead concentrations of male Albino rats treated with graded doses of lead for a period of four, eight and twelve weeks are shown in Table 1. Throughout the duration of treatment, there was a significant increase $(\mathrm{p}<0.05)$ in blood lead concentrations in the treated groups compared to the control group. The 400ppm treated group had the highest blood lead concentration irrespective of the duration of lead treatment. The group treated with 400ppm for four weeks had blood lead concentration of $19.76 \pm 0.47 \mu \mathrm{g} / \mathrm{dl}$ which was about 9.2 times higher than that of the control, while those treated for eight weeks had blood lead concentration of $39.82 \pm 1.14 \mu \mathrm{g} / \mathrm{dl}$ and those treated for twelve weeks had blood lead concentration of $63.50 \pm 1.65 \mu \mathrm{g} / \mathrm{dl}$ which was about 9.9 times higher than that of the control. 
Haemato-biochemical alterations toxicity in male wistar rats

Table 1. The mean blood lead concentrations of male Albino rats treated with graded doses of lead

\begin{tabular}{llll}
\hline & \multicolumn{3}{c}{ Blood lead concentration $(\mu \mathrm{g} / \mathrm{dl})(\mathrm{mean} \pm$ SEM) } \\
\hline Groups $(\mathrm{n}=6)$ & 4 weeks & 8 weeks & 12 weeks \\
\hline Control & $2.15 \pm 0.06 \mathrm{a}$ & $4.31 \pm 0.14 \mathrm{a}$ & $6.41 \pm 0.24 \mathrm{a}$ \\
$200 \mathrm{ppm}$ & $12.36 \pm 1.14 \mathrm{~b}$ & $28.35 \pm 1.57 \mathrm{~b}$ & $39.39 \pm 2.92 \mathrm{~b}$ \\
$300 \mathrm{ppm}$ & $13.16 \pm 1.00 \mathrm{~b}$ & $29.64 \pm 1.86 \mathrm{~b}$ & $43.60 \pm 2.77 \mathrm{~b}$ \\
$400 \mathrm{ppm}$ & $19.76 \pm 0.47 \mathrm{c}$ & $39.82 \pm 1.14 \mathrm{c}$ & $63.50 \pm 1.65 \mathrm{c}$ \\
\hline
\end{tabular}

Values within the same column with different superscripts are significantly different at $\mathrm{p}<0.05$

There was a significant decrease $(\mathrm{p}<0.05)$ in the packed cell volume at varying doses of exposure, most especially at higher dose of $400 \mathrm{ppm}$ for duration of 12 weeks in which there was almost $50 \%$ reduction in packed cell volume compared to the control group. The haemoglobin concentrations also followed similar pattern as the packed cell volume (Table 2).

Table 2. The mean packed cell volume and haemoglobin concentrations of male albino rats treated with graded dose

\begin{tabular}{lllllll}
\hline \multicolumn{3}{c}{ Packed cell volume (\%) $($ mean \pm SEM) } & \multicolumn{3}{l}{ Haemoglobin concentration (g/dl) (mean \pm SEM) } \\
\hline Group $(\mathrm{n}=6)$ & 4 weeks & 8 weeks & 12 weeks & 4 weeks & 8 weeks & 12 weeks \\
\hline Control & $49.75 \pm 1.06 \mathrm{a}$ & $48.61 \pm 1.98 \mathrm{a}$ & $45.12 \pm 1.11 \mathrm{a}$ & $16.12 \pm 3.11 \mathrm{a}$ & $15.51 \pm 2.13 \mathrm{a}$ & $16.72 \pm 2.01 \mathrm{a}$ \\
$200 \mathrm{ppm}$ & $42.01 \pm 1.21 \mathrm{a}$ & $40.11 \pm 1.28 \mathrm{~b}$ & $34.01 \pm 0.13 \mathrm{~b}$ & $14.01 \pm 2.11 \mathrm{a}$ & $13.00 \pm 2.20 \mathrm{a}$ & $15.21 \pm 1.08 \mathrm{a}$ \\
$300 \mathrm{ppm}$ & $40.11 \pm 1.13 \mathrm{~b}$ & $37.01 \pm 1.13 \mathrm{c}$ & $32.11 \pm 1.01 \mathrm{~b}$ & $11.11 \pm 1.04 \mathrm{~b}$ & $9.85 \pm 1.13 \mathrm{~b}$ & $13.33 \pm 1.13 \mathrm{c}$ \\
$400 \mathrm{ppm}$ & $39.12 \pm 1.11 \mathrm{~b}$ & $34.11 \pm 1.04 \mathrm{c}$ & $29.01 \pm 0.13 \mathrm{c}$ & $9.01 \pm 1.13 \mathrm{~b}$ & $8.11 \pm 0.19 \mathrm{~b}$ & $7.11 \pm 0.18 \mathrm{c}$ \\
\hline
\end{tabular}

Values within the same column with different superscripts are significantly different at $\mathrm{p}<0.05$

Table 3 shows the mean red blood cell indices as measured by MCV, MCH and MCHC. There were significant reductions $(\mathrm{p}<0.05)$ in $\mathrm{MCV}, \mathrm{MCH}$ and $\mathrm{MCHC}$ in all the dose groups. The reduction was found to be dose-dependent. At highest dose (400 ppm), reduction in MCV was found to be about 50\% compared to the control group. A similar pattern was also observed in $\mathrm{MCH}$ and $\mathrm{MCHC}$.

Table 3. MCV, MCH and MCHC of male Albino rats treated with graded doses of lead for different periods

\begin{tabular}{|c|c|c|c|c|c|c|c|c|c|}
\hline & \multicolumn{3}{|c|}{ MCV (fl) (mean \pm SEM) } & \multicolumn{3}{|c|}{ MCH (pg) (mean \pm SEM) } & \multicolumn{3}{|c|}{ MCHC (\%)(mean士SEM) } \\
\hline & 4 week & 8 week & 12 week & 4 week & 8 week & 12 week & 4 week & 8 week & 12 week \\
\hline Control & $59.4 \pm 1.0^{\mathrm{a}}$ & $62.2 \pm 0.7^{\mathrm{a}}$ & $57.1 \pm 0.3^{\mathrm{a}}$ & $20.4 \pm 0.1^{\mathrm{a}}$ & $21.2 \pm 0.1^{\mathrm{a}}$ & $19.1 \pm 0.2^{\mathrm{a}}$ & $34.4 \pm 0.4^{\mathrm{a}}$ & $35.0 \pm 0.2^{\mathrm{a}}$ & $32.2 \pm 0.1^{\mathrm{a}}$ \\
\hline 200 ppm & $58.8 \pm 1.0^{\mathrm{a}}$ & $52.6 \pm 0.1^{\mathrm{b}}$ & $51.9 \pm 0.1^{\mathrm{b}}$ & $18.2 \pm 0.1^{\mathrm{a}}$ & $17.1 \pm 0.1^{\mathrm{b}}$ & $17.1 \pm 0.1^{\mathrm{a}}$ & $30.2 \pm 0.2^{b}$ & $30.1 \pm 0.2^{b}$ & $29.1 \pm 0.3^{b}$ \\
\hline 300 ppm & $30.1 \pm 0.6^{\mathrm{b}}$ & $40.1 \pm 0.1^{\mathrm{c}}$ & $29.1 \pm 0.2^{\mathrm{c}}$ & $14.1 \pm 0.2^{b}$ & $10.0 \pm 0.1^{\mathrm{c}}$ & $15.0 \pm 0.1^{\mathrm{b}}$ & $33.2 \pm 0.1^{\mathrm{b}}$ & $28.1 \pm 0.1^{\mathrm{b}}$ & $20.2 \pm 0.3^{b}$ \\
\hline $400 \mathrm{ppm}$ & $29.0 \pm 0.5^{c}$ & $38.1 \pm 0.2^{\mathrm{c}}$ & $30.1 \pm 0.2^{c}$ & $12.0 \pm 0.1^{b}$ & $10.1 \pm 0.1^{\mathrm{c}}$ & $9.2 \pm 0.1^{\mathrm{c}}$ & $28.1 \pm 0.2^{b}$ & $30.1 \pm 0.1^{\mathrm{c}}$ & $18.2 \pm 0.1^{\mathrm{b}}$ \\
\hline
\end{tabular}

Values are Values within the same column with different superscripts are significantly different at $\mathrm{p}<0.05$

There was a significant decrease $(\mathrm{p}<0.05)$ in the plasma protein in all the dose groups compared to the control group. However, there was no significant change in the albumin concentration at four week treatment, but treatment for eight and twelve weeks produced a significant decrease $(p<0.05)$ in the albumin concentrations (Table 4).

Table 4. The mean total plasma protein and albumin concentrations of male Albino rats treated with graded doses

\begin{tabular}{lllllll}
\hline \multicolumn{3}{c}{ Total plasma protein $(\mathrm{g} / \mathrm{dl})(\mathrm{mean} \pm \mathrm{SEM})$} & \multicolumn{3}{c}{ Albumin $(\mathrm{g} / \mathrm{dl})(\mathrm{mean} \pm \mathrm{SEM})$} \\
\hline Groups $(\mathrm{n}=6)$ & 4 weeks & 8 weeks & 12 weeks & 4 weeks & 8 weeks & 12 weeks \\
\hline Control & $7.00 \pm 0.41 \mathrm{a}$ & $6.94 \pm 0.39 \mathrm{a}$ & $7.07 \pm 0.30 \mathrm{a}$ & $4.60 \pm 0.26 \mathrm{a}$ & $4.01 \pm 0.22 \mathrm{a}$ & $4.22 \pm 0.29 \mathrm{a}$ \\
$200 \mathrm{ppm}$ & $4.59 \pm 0.22 \mathrm{~b}$ & $4.11 \pm 0.21 \mathrm{~b}$ & $4.01 \pm 0.21 \mathrm{~b}$ & $4.11 \pm 0.12 \mathrm{a}$ & $2.59 \pm 0.11 \mathrm{~b}$ & $2.87 \pm 0.13 \mathrm{~b}$ \\
$300 \mathrm{ppm}$ & $4.72 \pm 0.29 \mathrm{~b}$ & $3.17 \pm 0.11 \mathrm{c}$ & $4.22 \pm 0.34 \mathrm{~b}$ & $4.22 \pm 0.25 \mathrm{a}$ & $2.40 \pm 0.13 \mathrm{~b}$ & $2.51 \pm 0.17 \mathrm{~b}$ \\
$400 \mathrm{ppm}$ & $4.50 \pm 0.30 \mathrm{~b}$ & $4.21 \pm 0.09 \mathrm{~b}$ & $3.04 \pm 0.21 \mathrm{c}$ & $3.01 \pm 0.11 \mathrm{~b}$ & $2.14 \pm 0.12 \mathrm{~b}$ & $2.40 \pm 0.16 \mathrm{~b}$ \\
\hline
\end{tabular}

Values within the same column with different superscripts are significantly different at $\mathrm{p}<0.05$ 


\section{B. S. Okediran and others}

Table 5 shows the mean blood urea nitrogen and creatinine concentrations of male Albino rats treated with graded doses of lead for a period of four, eight and twelve weeks. There was significant increase $(p<0.05)$ in both the blood urea nitrogen and creatinine concentration in all the dose groups. The increase was more prominent at higher treament dose of 400 ppm of lead.

Table 5. The mean blood urea nitrogen (BUN) and creatinine concentrations of male Albino rats treated with graded doses of lead for a period of four, eight and twelve weeks

\begin{tabular}{lllllll}
\hline & \multicolumn{2}{c}{ BUN concentrations (mg/dl) } & \multicolumn{2}{c}{ Creatinine concentrations (mg/dl) } \\
\hline Groups & 4 weeks & 8 weeks & 12 weeks & 4 weeks & 8 weeks & 12 weeks \\
\hline Control & $17.97 \pm 2.98 \mathrm{a}$ & $17.66 \pm 2.71 \mathrm{a}$ & $17.99 \pm 2.57 \mathrm{a}$ & $0.95 \pm 0.02 \mathrm{a}$ & $0.90 \pm 0.04 \mathrm{a}$ & $0.78 \pm 0.01 \mathrm{a}$ \\
$200 \mathrm{ppm}$ & $18.67 \pm 1.08 \mathrm{a}$ & $20.14 \pm 2.11 \mathrm{~b}$ & $25.11 \pm 2.01 \mathrm{~b}$ & $1.04 \pm 0.01 \mathrm{a}$ & $1.62 \pm 0.03 \mathrm{~b}$ & $1.62 \pm 0.03 \mathrm{~b}$ \\
$300 \mathrm{ppm}$ & $24.11 \pm 1.22 \mathrm{~b}$ & $24.66 \pm 1.74 \mathrm{~b}$ & $30.44 \pm 1.11 \mathrm{c}$ & $1.11 \pm 0.01 \mathrm{a}$ & $1.70 \pm 0.03 \mathrm{~b}$ & $1.77 \pm 0.04 \mathrm{~b}$ \\
$400 \mathrm{ppm}$ & $26.78 \pm 1.34 \mathrm{~b}$ & $26.75 \pm 2.91 \mathrm{~b}$ & $34.27 \pm 2.46 \mathrm{c}$ & $1.27 \pm 0.04 \mathrm{~b}$ & $1.89 \pm 0.03 \mathrm{~b}$ & $1.93 \pm 0.06 \mathrm{~b}$ \\
\hline
\end{tabular}

Lead is a major environmental pollutant and its toxicity continues to be a major public health problem and there is a growing consensus that lead cause toxic injury to human at a level of exposure that was considered to be safe only a decade ago.

Our result shows that following oral exposure to lead, there was an increased in the blood lead concentration which was dose dependent. This can be associated to rapid absorption of lead following ingestion which are rapidly absorbed and transported by blood to various tissues. The obtained results are in agreement with earlier studies (Okediran et al., 2009; Moussa and Bashandy, 2008) who reported accumulation in blood lead following oral exposure with significant reduction in weight.

Anaemia that accompanies lead poisoning is in part the result of various inhibitory effects of lead on heme biosynthesis. On the other hand, lead also increase the rate of red cell destruction and shortened red cell survival (Yangho et al., 2002). The result of this study shows significant reduction in both the packed cell volume and haemoglobin concentration, owing to the fact that lead intoxication causes a documented defect in haem synthesis (Nabil, et al., 2012; Duruibe, 2007) The reduction in haemoglobin concentration confirmed the decrease in packed cell volume which is attributed to the toxicity of lead acetate. It is possible that lead can cause anaemia and even growth retardation because the action of lead is particularly marked in the blood vessel and some effects are secondary to this injury (Reza et al., 2009). The reduction in red blood cells, packed cell volume, haemoglobin concentration, mean corpuscular volume, mean corpuscular haemoglobin and mean corpuscular haemoglobin concentration observed in this study following lead exposure revealed microcytic hypochromic anaemia. The results obtained agreed with several authors (Okediran et al., 2009; Helmy et al., 2000; Jain, 1986) because lead pollution has an inhibitory effect on globin synthesis, inhibits iron to form haem and inhibits delta amino levulinic acid dehydratase in red cells. Moreover lead also inhibits the conversion of coproporphyrinogen iii to protoporphyrin ix leading to reduction in haemoglobin production and shortened life span of erythrocytes (Suradkar et al., 2009; Klassen, 2001).

Biochemical results detected significant decrease in plasma total protein and albumin while creatinine and blood urea nitrogen revealed significant increase. About $9 \%$ of inorganic lead is transported mainly in the plasma (McLntire and Angle, 1972), while albumin in plasma is used as carrier for lead. Heavy metals including lead can precipitate soluble protein (Nabil et al., 2012). The reduction in plasma total protein and albumin may be due to inhibition of protein and albumin biosynthesis through the specific enzymes in the cell processes, also may be due to decrease utilization of free amino acids for protein synthesis. Lead also binds to plasma proteins where it causes alterations in high number of enzymes and can also pertub protein synthesis in hepatocytes (Georing, 1993). Swarp et al. (2007) also reported decreased total plasma protein and albumin concentrations which were attributed to liver injury due to significant increase in the plasma transaminases. 
Elevation of blood urea nitrogen and creatinine was observed in this studies which are indicative of abnormal kidney functions agreed with those of Goswami et al., (2005). Increase in creatinine concentration might be due to loss of appreciable loss of kidney function and considered as functional evidence of lead induced nephrotoxicity $(\mathrm{Qu}, 2002)$. However significant decrease in creatinine and blood urea nitrogen was reported in lead acetate rats (Rumana et al., 2002). The observed increase in blood urea nitrogen and creatinine caused by lead suggest that renal function impairment which might result from intrinsic renal lesions, decreased perfusion of the kidney obstruction of lower urinary tract or due to deranged metabolic process caused by this metal (Cameron and Greger, 1998). Rats treated with lead had significantly decreased urine urea and slight increase in serum urea has been reported to increase in acute and chronic intrinsic renal disease and also when there is decreased renal perfusion (Cameron and Greger, 1998). Ghorbe et al. (2001) illustrated that oral administration of lead acetate caused significant increase in blood urea and serum creatinine.

The observations in this study suggest that the alterations in both the haematological and biochemical parameters were produced by lead at varying doses over a period of time. It was concluded that oral exposure to lead at vary doses over a period of four, eight and twelve weeks results in alterations of various haematological and biochemical parameters and thus can serve as a sensitive biomarkers in lead toxicity.

\section{REFERENCES}

1. Cameron JS and Greger R (1998). Renal function and testing of function (Davidson AM, Cameron JS, Grunfeld JP, Kerr DNS, Rits E, Winearl GC eds.) Oxford Textbok of Clinical Nephrology 36-39.

2. Duruibe JO, Ogwuegbu MOC and Egwurugwu JN. (2007). Heavy metal pollution and human biotoxic effects. International Journal of Physiological Sciences 2: 112-118

3. Finkel AJ, Hamilton A and Hardy HL (1983). Metals and metalloids. In: Finkel AJ editor. Industrial toxicity, $4^{\text {th }}$ ed. Boston, London: John Wright PSG, 62-67

4. Georing PL (1993). Lead-protein interaction as a basis for lead toxicity. Neurotoxicology 14: 45-60

5. Ghorbe F, Boujelbene M, Makni-Ayadi F, Guermazi F, Kammoun A, Murat J, Croute F, Soleilhavoup JP and Feki AE (2001). Effect of chronic lead Exposure on kidney function in male and female Rats: Determination of a lead Exposure Biomarker. Physiology and Biochemistry 5: 457-467.

6. Goswami K, Gachhui R and Bandopadhyay A (2005). Hepatorenal dysfunction in lead pollution. England Journal of Environmental Sciences 47: 75-80.

7. Grant GH (1987). Amino acids and protein; fundamentals of clinical chemistry, N.W. Tietz (ed) WB Saunders company Philadelphia USA. 328-329

8. Harrison RM and Laxen DPH (1981). Lead in atmosphere. In: Harrison RM, Laxen DPH, (eds.). Lead pollution causes and control, New York: Chapman and Hall, 7-11.

9. Helmy MA, Einaa NI and Hela SM (2000). Effect of administration of milk and kareish cheese on haematological and histological changes in liver and brain of rats treated with lead. Alexandria Journal of Agricultural Research 45(2): 103-115

10. Jain SD (1986). Evaluation of haemogram in healthy and diseased sheep. Research in Veterinary Sciences 33: 21.

11. Klassen CD (2001). Cassarett and Doull's Toxicology: The basic Science of poisons. $6^{\text {th }}$ edn. McGraw-Hill Medical publishing division PP. 812-841

12. Lamphear BP, Howard C and Eberly S (1999). Primary prevention of childhood lead exposure: a randomized trial of dust control. Pediatrics 103: 772-777.

13. Mc-Lntire MS and Angle CR (1972). Air lead: relation to lead in blood of black school children deficient in glucose-6-phosphate dehydrogenase. Sciences 177: 520-522

14. Moussa SA and Bashandy SA (2008). Biophysical and biochemical changes in the blood of rats exposed to lead toxicity. Romanian Journal of Biophysics 18: 123-133.

15. Nabil MI, Esam AE, Hossam, SE and Yasmin EA (2012). Effect of lead acetate toxicity on experimental male albino rat. Asian Pacific Journal of Tropical Biomedicine 2: 41-46

16. Nevin ES, Mona SZ, Hend RG, Nabila EB and Olfat MF (2008). Some clinicopathological and microbiological studies on lead toxicity in bull. America-European Journal of Agricultural and Environmental Sciences 3: 165-168.

17. Okediran BS, Abam E, Odukoya OO, Adamson I and Ademuyiwa O (2009). Membrane, intracellular, plasma and urinary sodium and potassium in occupational lead exposure: Effects of vitamin C supplementation. Trace Element Electrolytes 26: 49-59. 


\section{B. S. Okediran and others}

18. Qu W (2002). The metallothionein-null phenotype is associated with heightened sensitivity to lead toxicity and an inability to form inclusion bodies. American Journal of Pathology 160: 1047-1056.

19. Reza B, Ali N, Mustafa M, Alireza A and Ali K (2009). Cardiac responsiveness to beta-adrenergic in rats with leadinduced. Biological Medicine 1: 75-81

20. Rumana S, Mishra GV and Vohora SB (2002). Effect of therapeutic doses of calcined arsenic and lead preparation in rats. International Journal of Veterinary Pathology 26: 81-82.

21. Silbergeld EK (1997). Preventing lead poisoning in children. Annual Review of Public Health 18: 801-810.

22. Suradkar SG, Ghodasara DJ, Priti V, Jatin P, Vikas J and Prajapati KS (2009). Haemato-Biochemical Alterations induced by lead acetate toxicity in Wistar Rats. Veterinary World 2: 429-431.

23. Swarp D, Naresh, R, Varshney VP, Balganatharathilagar M, Kumar P, Nandi D and Patral RD (2007). Changes in plasma hormone profile and liver functions in cows naturally exposed to lead and cadmium around different industrial areas. Research in Veterinary Sciences 82: 16-21.

24. Tietz NW (1995). Clinical guide to laboratory tests. $3^{\text {rd }}$ (ed). W.B. Saunders company, Philadelphia. 518-519.

25. Yangho KIM, Cheol-In YOO, Choong Ryeol LEE, Ji Ho LEE, Sung-Ryul KIM, Seoung-Hoon CHANG, Won-Jin LEE, Cheon-Hyun HWANG and Young Hwan LEE (2002). Evaluation of activity of erythrocyte Pyrimidine 5'Nucleotidase (P5N) in Lead Exposed Workers: with Focus on the Effect on Haemoglobin. Industrial Health 40: 23-27. 